\title{
Correlation Between Mobility and COVID-19 Cases in Surabaya City, Indonesia
}

\author{
Gholiqul Amrodh Alawy ${ }^{1}$, Achmad Wicaksono ${ }^{1}$, Agus Suharyanto ${ }^{1}$ \\ ${ }^{1}$ Department of Civil Engineering, Faculty of Engineering, Universitas Brawijaya, \\ Malang, 65145, Indonesia \\ gholiqulaa@gmail.com
}

Received 25-05-2021; accepted 29-06-2021

\begin{abstract}
The number of COVID-19 cases in Surabaya was one of the highest in Indonesia at the beginning of the pandemic. This study aims to determine the mobility and activity patterns of the people of Surabaya during the COVID-19 pandemic and find a correlation between people mobility and the number of COVID-19 cases in Surabaya City using Pearson's Coefficient of Correlation (PCC). The data used are mobility data at Gubeng Station, Purabaya Terminal, Waru Utama toll gate, and COVID-19 Community Mobility Reports. The mobility pattern of the people of Surabaya City in 2020 is divided into 5 phases, namely the normal condition phase (F0), the pandemic's initial phase (F1), the PSBB phase (F2), the transition of AKB phase (F3), and the AKB phase (F4). This study indicates that the number of people in transit stations and residential areas has a high correlation with the number of COVID-19 cases. In addition, the type of mobility that has the most effect on increasing the number of COVID-19 cases is the mobility of bus transportation.
\end{abstract}

Keywords: Activity, Correlation, COVID-19, Mobility, Transportation.

\section{Introduction}

The COVID-19 pandemic began in early 2020 and entered Indonesia on March 2, 2020, in Depok [1]. The number of positive cases of COVID-19 in Indonesia continues to increase until January 26, 2021, and COVID-19 confirmed patients in Indonesia reached 1,000,000 more people [2].

The number of positive cases in Surabaya, one of the major cities in Indonesia, had a very high increase at the beginning of the pandemic. On $20-25$ May 2020, the number of people confirmed positive for COVID-19 almost doubled from 1,255 people to 2,095 people [2]. It is estimated that the high people mobility is due to the homecoming flow ahead of Eid al-Fitr $1441 \mathrm{H}$.

The Government of Indonesia has tried to prevent the transmission of this virus by issuing various policies of social and transportation restrictions. Human mobility is one of the main factors in spreading the virus from the affected areas [3]. At the beginning of the spread of COVID-19 in Wuhan City, the

Cite this as: Alawy, G.A., Wicaksono, A. \& Suharyanto, A. (2021). Correlation Between Mobility and COVID19 Cases in Surabaya City, Indonesia. Civil and Environmental Science Journal (Civense), 4(2), 154-162. doi: https://doi.org/10.21776/ub.civense.2021.00402.5 
number of new cases outside Wuhan City substantially correlated to the volume of human mobility from Wuhan to other cities [4]. The pandemic has an impact on the economy and the welfare of people in Indonesia. It takes research that provides a view for transport policy makers, planners, and researchers to map the situation to restore its state [5].

This study aims to determine the relationship between COVID-19 cases and the mobility of people and vehicles in Surabaya. In addition, this study also examines government policies that impact the travel patterns of the people of Surabaya during a pandemic. The results of this study are expected to help the central and local governments in taking policy related to transportation during the pandemic.

\section{Material and Methods}

The research area is Surabaya City, the center of movement and activity, and the coronavirus was first spread in East Java Province. The data used is secondary daily data from the beginning of COVID19 cases in Surabaya until the end of 2020, March 17 -December 31, 2020.

The number of positive COVID-19 data in Surabaya and mobility data will be juxtaposed with government policies related to transportation, public transport, and social restrictions. Furthermore, it can be known that the pattern of people's mobility in 2020 can be divided into several stages/ phases.

In each phase, the correlation between the number of COVID-19 cases and mobility in Surabaya will be calculated. This analysis aims to determine the extent of the relationship between each variable and look for the type of mobility that has the most impact on the increase in COVID-19 cases in Surabaya.

\subsection{Dataset}

The data used in this study is secondary data obtained from several agencies/ institutions, as shown in Table 1. The data collected are the number of COVID-19 positive cases, transportation policies during the pandemic, number of passengers on public transportation, volume of vehicles on toll roads, and community activities.

Table 1. Mobility data of Surabaya people used in research and institutions that provide such data.

\begin{tabular}{|c|c|c|}
\hline No. & Data & Institutions \\
\hline 1 & $\begin{array}{l}\text { COVID-19 Cases in } \\
\text { Surabaya City }\end{array}$ & $\begin{array}{l}\text { Ministry of Health Republic of Indonesia } \\
\text { (https://infocovid19jatimprov.go.id/) }\end{array}$ \\
\hline 2 & $\begin{array}{l}\text { Passengers and Vehicles } \\
\text { in Purabaya Bus Station }\end{array}$ & Surabaya Transportation Department (DISHUB) \\
\hline 3 & $\begin{array}{l}\text { Passengers in Gubeng } \\
\text { Train Station }\end{array}$ & PT. Kereta Api Indonesia DAOP VIII Surabaya \\
\hline 4 & $\begin{array}{l}\text { Vehicles in Waru Utama } \\
\text { Toll Gate }\end{array}$ & PT. Jasa Marga Surabaya Gempol \\
\hline 5 & $\begin{array}{l}\text { Community Mobility } \\
\text { Reports in East Java }\end{array}$ & $\begin{array}{c}\text { Google Community Mobility Reports } \\
\text { (https://www.google.com/covid19/mobility/) }\end{array}$ \\
\hline
\end{tabular}

2.1.1. COVID-19 Cases. The first confirmed positive cases of COVID-19 in Surabaya and East Java provinces were announced on March 17, 2020. The number of positive cases of COVID-19 data obtained from the Ministry of Health of the Republic of Indonesia through the Government of East Java Province. The data for COVID-19 used is the number of confirmed positive cases of COVID-19, while data for patients recovered, patients died, and others were not used in this study.

2.1.2. Mobility in Terminal and Station. Vehicle and passenger data in this study have been taken from Gubeng Station and Purabaya Terminal. Both locations were chosen because they are the busiest land 
transportation nodes in the Greater Surabaya area. The train mobility data used is the data of passengers who boarded at Gubeng Station. While mobility data on buses used in this study are:

- Number of passengers and vehicles coming to Purabaya Terminal

- Number of passengers and vehicles departing from Purabaya Terminal

2.1.3. Mobility in Highway. Mobility data on the road taken is the number of vehicles entering the Surabaya through the Waru Utama Toll Gate. This toll gate was chosen because it is the main toll gate to enter the Surabaya area and has the highest traffic volume compared to other toll gates.

2.1.4. The activity of the community. Data on people's movement in East Java Province is obtained from mobility reports issued by Google based on tracking of mobile phone users in a region. The COVID-19 Community Mobility Report aims to provide insights into mobility changes in response to government policies to reduce the impact of COVID-19 [6]. This reporting is in the form of a percentage (\%) of people in a certain activity category with a baseline that is the median size from January 3 to February 6, 2020. Activity trends recorded in an area are divided into six categories of places: retail \& recreation, grocery \& pharmacy, parks, transit stations, workplaces, and residential.

\subsection{Method}

The correlation analysis used in this study used Pearson's Coefficient of Correlation (PCC) according to the equation (1) as follows:

$$
r_{x y}=\frac{n \sum x_{i}-\sum x_{i} \sum y_{i}}{\sqrt{n \sum x_{i}^{2}-\left(\sum x_{i}\right)^{2}} \sqrt{n \sum y_{i}^{2}-\left(\sum y_{i}\right)^{2}}}
$$

Where $x_{i}$ is called the independent variable, $y_{i}$ is the dependent variable, and $\mathrm{n}$ is the total sample. Pearson correlations in this study are appropriate because the datasets used have interval or ratio scales. The variables to be searched for correlation are shown in Table 2.

Table 2. Research variables and their code. Variables are divided into the variable number of positive COVID-19 (Y) and mobility variables of people/vehicles $\left(\mathrm{X}_{\mathrm{i}}\right)$.

\begin{tabular}{ccc}
\hline \multicolumn{2}{c}{ Research Variable } & Code \\
\hline \multirow{2}{*}{ Positive cases of COVID-19 in Surabaya } & $\mathrm{Y}_{1}$ \\
\hline \multirow{3}{*}{$\begin{array}{c}\text { Mobility in Purabaya } \\
\text { Bus Station }\end{array}$} & Vehicle coming & $\mathrm{X}_{11}$ \\
\cline { 2 - 3 } & Passenger coming & $\mathrm{X}_{12}$ \\
\cline { 2 - 3 } & Vehicle departing & $\mathrm{X}_{13}$ \\
\hline $\begin{array}{c}\text { Mobility in Gubeng } \\
\text { Train Station }\end{array}$ & Passenger departing & $\mathrm{X}_{14}$ \\
\hline Mobility in Waru Utama & Passenger departing & $\mathrm{X}_{21}$ \\
Toll Gate & Vehicle passing & \\
\cline { 2 - 3 } & Retail \& Recreation & $\mathrm{X}_{31}$ \\
\cline { 2 - 3 } & Grocery \& Pharmacy & $\mathrm{X}_{42}$ \\
\cline { 2 - 3 } Google Community \\
Mobility Report & Parks & $\mathrm{X}_{43}$ \\
\cline { 2 - 3 } & Transit Stations & $\mathrm{X}_{44}$ \\
\cline { 2 - 3 } & Workplaces & $\mathrm{X}_{45}$ \\
\hline
\end{tabular}


The results of the correlation analysis show the close relationship between the variable number of COVID-19 cases (Y) and the mobility variables (Xi). Correlations between variables are rated from the range of -1 to 1 , with 0 is no correlation, while -1 and 1 are perfect correlation. A correlation value of -1 is a perfect correlation with the opposite direction, while 1 is a perfect correlation in the same order. There is no exact condition of whether a particular correlation number indicates a high or weak correlation rate. A correlation number above 0.5 shows a high correlation, while below 0.5 a weak correlation [7].

\section{Result and Discussion}

\subsection{Mobility and Activity patterns}

Changes in the mobility and activity of Surabaya's people in 2020 are due to the presence of COVID19 and the government's social restriction policies to prevent transmission of the virus. These changes can be divided into several phases that show the trends and characteristics of the community's mobility. The mobility and activity of Surabaya people in 2020 can be divided into 5 phases, Normal Condition Phase (F0), Pandemic's Initial Phase (F1), Large-Scale Social Restriction Phase (F2), Transition of New Habit Adaptation Phase (F3), and New Habit Adaptation Phase (F4). Each phase of community mobility in Surabaya occurs at different times and is shown in Table 3.

Table 3. Mobility and activity pattern phases of Surabaya people in 2020. Steps are divided into five based on differences in mobility and activity patterns.

\begin{tabular}{clc}
\hline No & \multicolumn{1}{c}{ Phase } & Time \\
\hline 1 & Normal Condition Phase (F0) & 1 January - 16 March 2020 \\
2 & Pandemic's Initial Phase (F1) & 17 March - 21 April 2020 \\
3 & Large-Scale Social Restriction Phase (F2) & 22 April - 5 June 2020 \\
4 & Transition of New Habit Adaptation Phase (F3) & 9 June - 8 July 2020 \\
5 & New Habit Adaptation Phase (F4) & 9 July - 31 December 2020 \\
\hline
\end{tabular}

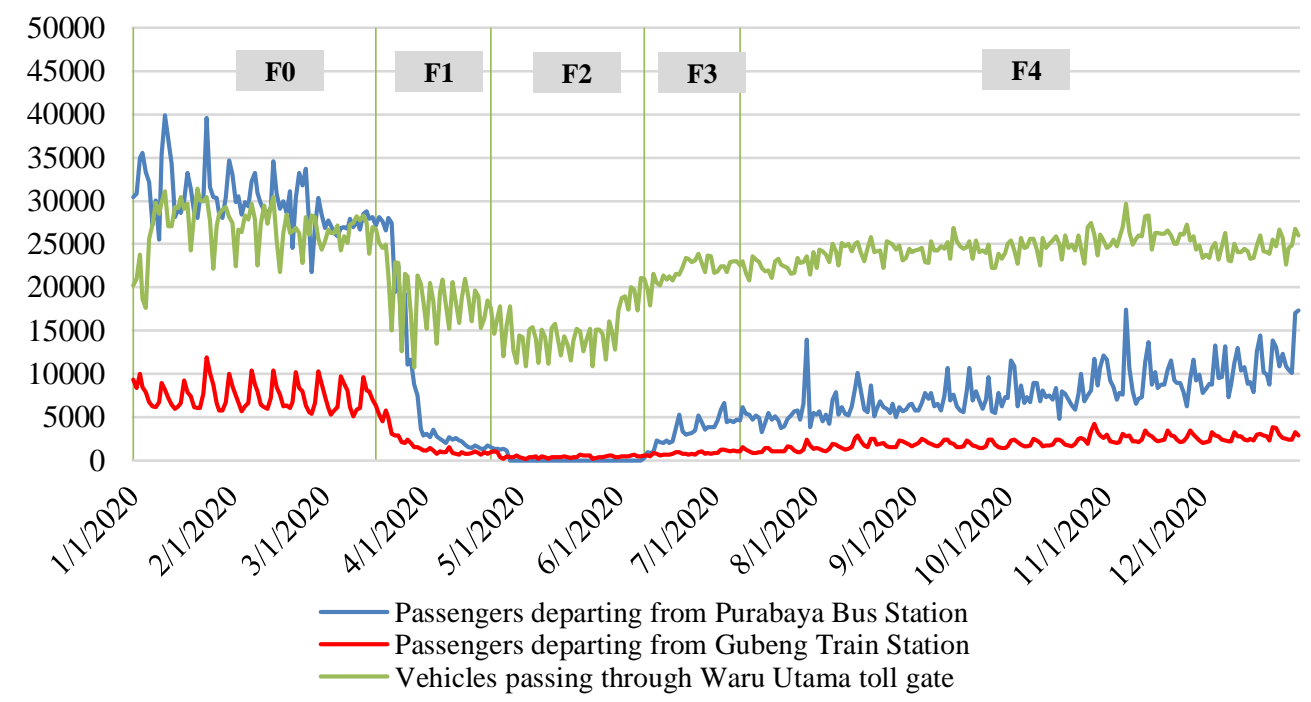

Figure 1. Fluctuations in people and vehicle's mobility every day in 2020. The difference in mobility patterns in each phase is seen in the graph, especially in the pre-pandemic phase with the post-pandemic phase. 
Mobility and activities of Surabaya people in 2020 are still normal at the beginning of the year, decreased due to COVID-19, and slowly increased until the end of the year. Fluctuations in people's mobility every day in 2020 are shown in the graph in Figure 1. In the chart, the mobility of people represented by vehicles passing through the Waru Utama toll gate, passengers departing from Purabaya bus station, and passengers departing from Gubeng train station. The percentage of mobility of people/vehicles in the post-pandemic phase (F1, F2, F3, F4) compared to the regular stage of prepandemic conditions (F0) is shown in Figure 2.

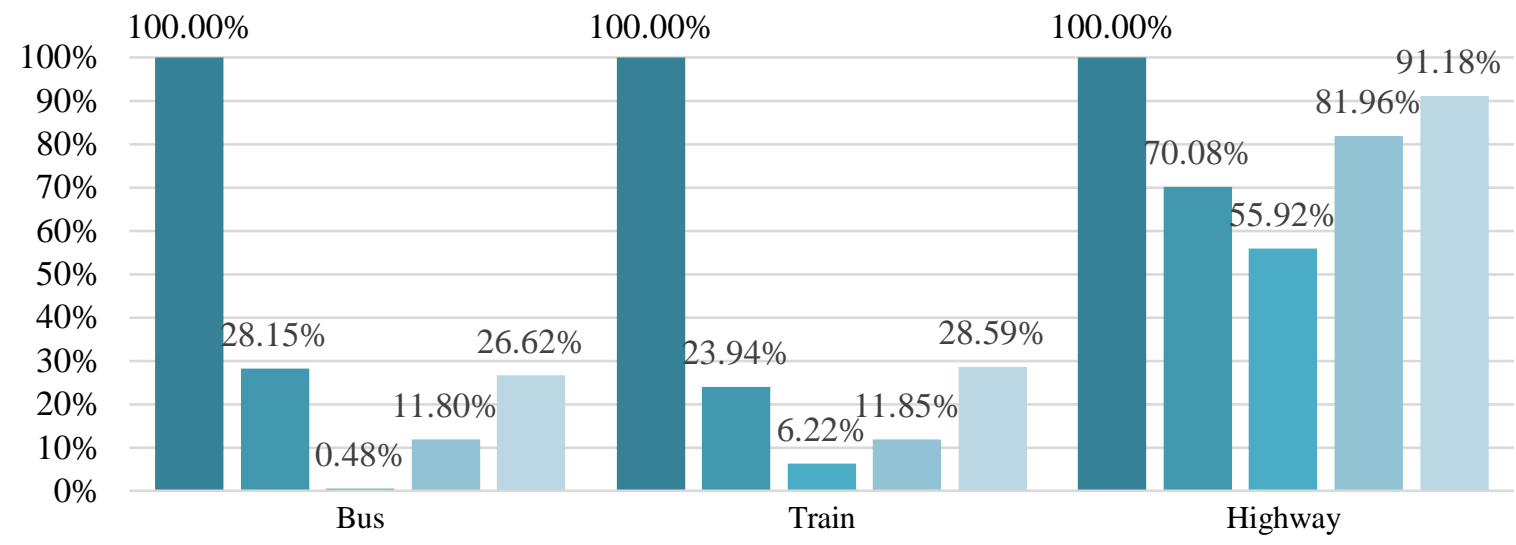

n Normal Condition Phase (F0) $\quad$ Pandemic's Initial Phase (F1) — PSBB Phase (F2) $\square$ Transition of AKB Phase (F3) $\llbracket$ AKB Phase (F4)

Figure 2. The percentage of mobility in the post-pandemic phase (F1, F2, F3, F4) compared to the normal phase of pre-pandemic conditions (F0).

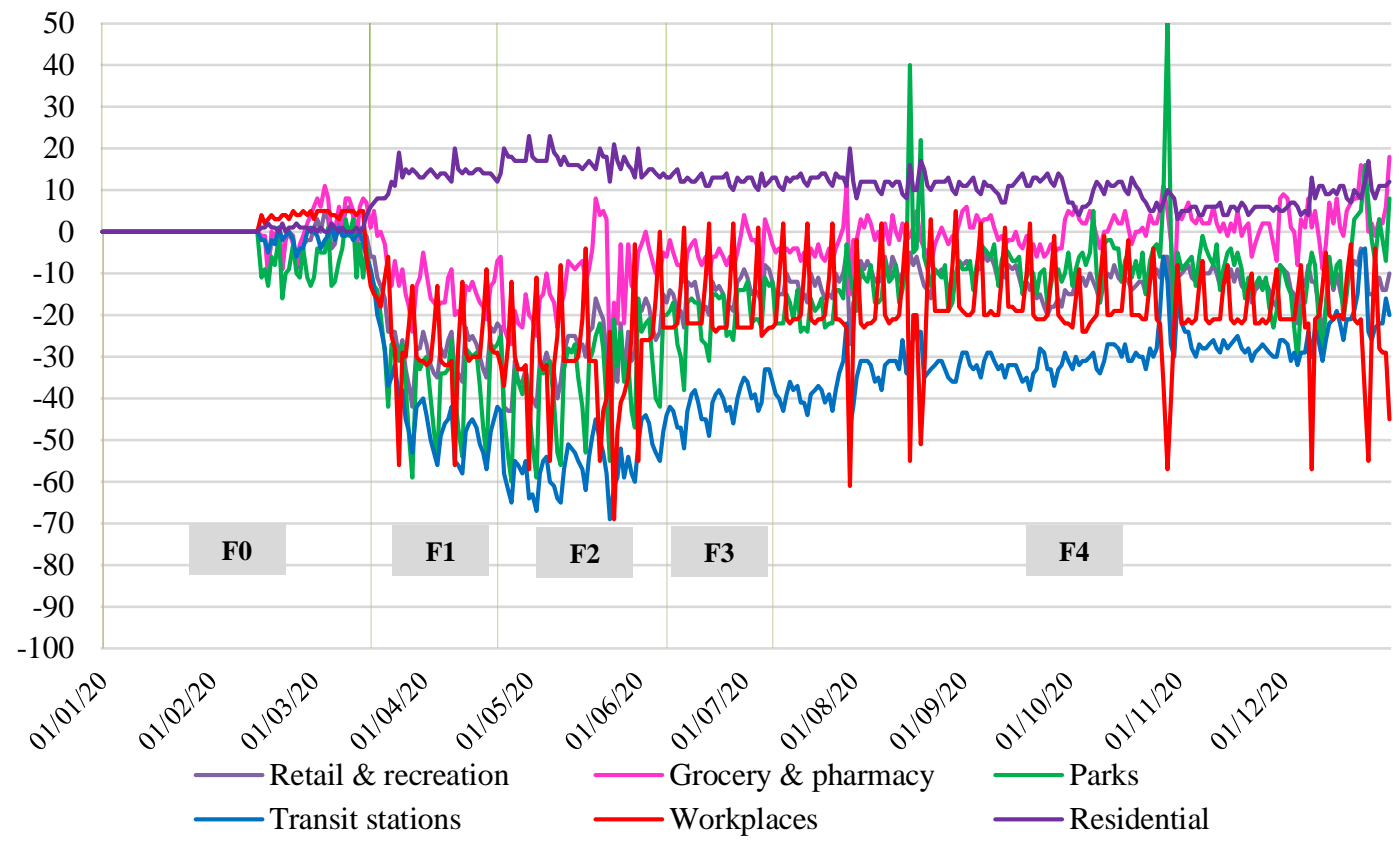

Figure 3. Fluctuations in people and vehicle's mobility every day in 2020 . The difference in mobility patterns in each phase is seen in the graph, especially in the pre-pandemic phase with the postpandemic phase. 
The pattern of community activity in some public places such as retail, recreation, grocery, pharmacy, parks, transit stations, and workplaces has fluctuations similar to mobility. Unlike general public sites, the percentage of people who are in residential has the opposite pattern. Changes in the rate of active people in several categories of places reported by the community mobility report in East Java every day in 2020 are shown in the graph in Figure 3. The percentage of people's activity in the postpandemic phase (F1, F2, F3, F4) compared to the regular stage of pre-pandemic conditions (F0) is shown in Figure 4.

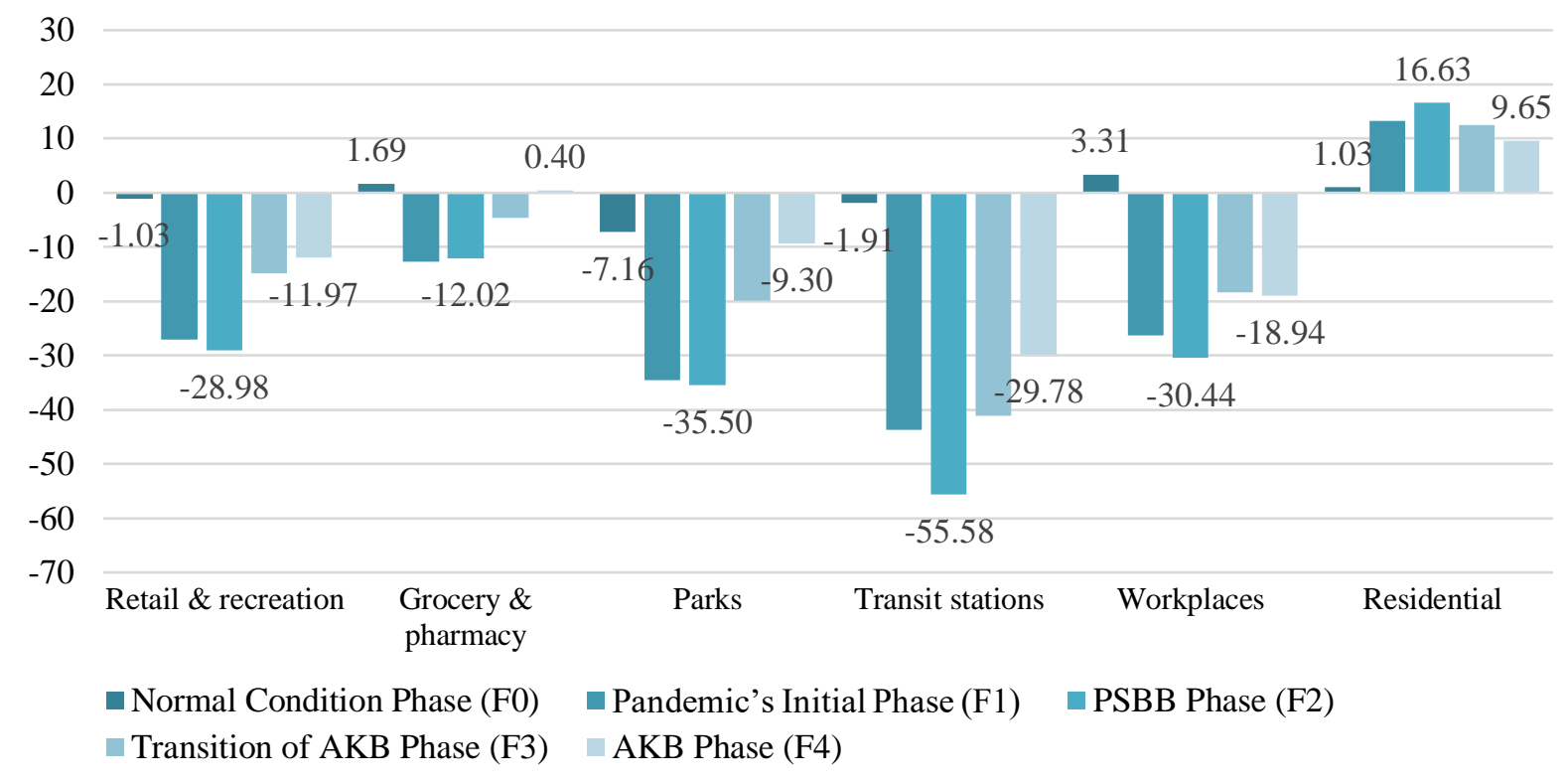

Figure 4. The percentage of mobility in the post-pandemic phase (F1, F2, F3, F4) compared to the normal stage of pre-pandemic conditions (F0).

3.1.1. Normal condition phase (F0). This phase starts from January 1, 2020, to March 16, 2020. In this phase, community activities are still normal. However, in early March, mobility decreased due to the emergence of the first case of COVID-19 in Indonesia. However, the decline is not significant and can still be categorized under normal conditions.

3.1.2. The Pandemic's Initial Phase (F1). On March 17, 2020, the first case was announced in Surabaya so that people prefer not to leave the house and do activities at home. This situation causes people's mobility to continue to decline; this phase is called the pandemic's initial phase (F1). Compared to F0, on F1 public transport using buses and trains disembarked to the remaining $28,15 \%$ and $23,94 \%$ [8] [9] respectively. Vehicles crossing the motorway are also reduced to $70,08 \%$ [10] when compared to F0.

3.1.3. Large-Scale Social Restriction Phase (F2). Due to the increasing number of COVID-19 cases, the local government finally issued a Large-Scale Social Restrictions (PSBB) policy for Surabaya and surrounding areas which continues to be extended until June 5, so this phase is called the Large-Scale Social Restriction (PSBB) phase (F2). This policy makes people's mobility decrease drastically to the lowest number in 2020. Some public facilities and public services are closed. One of them is the Purabaya bus transportation terminal temporarily suspended from April 28 to June 8, 2020. In addition, the Railway Station is still operating, but train passengers are very few with only $5 \%$ left compared to normal F0 conditions. 
3.1.4. The transition of New Habit Adaptation Phase (F3). Through SE Gugus Tugas No. 72020 on June 6, 2020, the government finally loosened social restrictions and began initiating new habit adaptation (AKB). On June 9, 2020, all public transportation in Surabaya was re-operated but still not entirely stable. This phase transitions between the condition of total social restriction in the PSBB phase and the state of the loosening of social restrictions in the AKB phase, so it is called the transition of the AKB phase (F3).

3.1.5. New Habit Adaptation Phase (F4). People's mobility has started to stabilize after one month of AKB policy issued, although it is still not as big in normal conditions before the pandemic. July 9, 2020, until the end of 2020, is called the AKB Phase (F4). Although it has started to stabilize, the mobility of people in F4 is still deficient compared to the normal condition phase (F0). Compared to normal conditions, bus and rail transport mobility is only $27 \%$ and $29 \%$ [3] [4]. Mobility of vehicles on the highway has started to approach normal conditions before the pandemic, which is $91 \%$ compared to normal conditions [5].

\subsection{Correlation between Mobility and COVID-19 Cases}

In this study, correlation values between the variable number of COVID-19 cases with mobility variable are using Pearson's Coefficient of Correlation (PCC) method. This analysis aims to find out the extent of the impact of COVID-19 on the mobility of people in Surabaya and vice versa. The analysis of research variable correlation is divided into two parts; the first is the correlation between the number of COVID-19 cases with passenger/vehicle mobility, and the second is the correlation between the number of COVID-19 cases and community activities from Community Mobility Reports (CMR).

The correlation between COVID-19 cases and the passenger/vehicle mobility in each phase is shown in Table 4. Mobility in bus transportation $\left(\mathrm{X}_{11}, \mathrm{X}_{12}, \mathrm{X}_{13}, \mathrm{X}_{14}\right)$ and on rail transport $\left(\mathrm{X}_{21}\right)$ relatively has a high correlation with the number of COVID-19 cases in Surabaya in the F1, F3, and F4 phases. In F2, the correlation value tends to be small due to lockdown conditions so that people's mobility does not have much effect on the addition of COVID-19 cases in Surabaya.

Table 4. Correlation of the number of COVID-19 cases with the mobility of people/vehicles in each phase. In F0, there is no correlation because there are no cases of COVID-19 in Surabaya.

\begin{tabular}{cccccc}
\hline Variable & F0 & F1 & F2 & F3 & F4 \\
\hline $\mathrm{Y}_{1}$ & - & 1 & 1 & 1 & 1 \\
$\mathrm{X}_{11}$ & - & -0.738 & -0.409 & 0.847 & 0.580 \\
$\mathrm{X}_{12}$ & - & -0.661 & -0.408 & 0.807 & 0.622 \\
$\mathrm{X}_{13}$ & - & -0.717 & -0.409 & 0.929 & 0.701 \\
$\mathrm{X}_{14}$ & - & -0.646 & -0.410 & 0.835 & 0.688 \\
$\mathrm{X}_{21}$ & - & -0.600 & 0.042 & 0.802 & 0.753 \\
$\mathrm{X}_{31}$ & - & -0.306 & 0.310 & 0.632 & 0.568 \\
\hline
\end{tabular}

On the pandemic's initial phase (F1) and the PSBB phase (F2), the negative correlation values indicate that the relationship between the number of cases and mobility is reversed. This value shows that in the initial phases of the pandemic, the number of COVID-19 cases continues to increase per day. The number of mobility decreases because people are infected by the virus and the government's advice to work and school from home. In F1, the correlation value is relatively high, which means an increase in the number of COVID-19 cases with a decrease in people's mobility is closely related.

On F3 and F4, the correlation value obtained relatively high with a positive coefficient indicates that the number of cases with mobility has a close and direct relationship. This value shows that the increasing number of people's mobility in the new habit adaptation phase has a high relationship with 
the increase in the number of COVID-19 cases in Surabaya. In F3, the correlation value is higher than $\mathrm{F} 4$, which indicates that although mobility and community activity has increased towards normal in F4, the increase in the number of cases is not very significant and can already be controlled.

Furthermore, the correlation between COVID-19 cases and community activities in the city in each phase is shown in Table 5.

Table 5. Correlation of the number of COVID-19 cases with community activities in the city for each phase. In F0, there is no correlation because there are no cases of COVID-19 in Surabaya.

\begin{tabular}{cccccc}
\hline Variable & F0 & F1 & F2 & F3 & F4 \\
\hline $\mathrm{Y}_{1}$ & - & 1 & 1 & 1 & 1 \\
$\mathrm{X}_{41}$ & - & -0.269 & 0.480 & 0.457 & -0.048 \\
$\mathrm{X}_{42}$ & - & -0.447 & 0.401 & 0.447 & 0.440 \\
$\mathrm{X}_{43}$ & - & -0.232 & 0.369 & 0.382 & 0.281 \\
$\mathrm{X}_{44}$ & - & -0.544 & 0.262 & 0.615 & 0.688 \\
$\mathrm{X}_{45}$ & - & -0.057 & -0.102 & -0.034 & -0.090 \\
$\mathrm{X}_{46}$ & - & 0.377 & -0.292 & -0.302 & -0.573 \\
\hline
\end{tabular}

In the pandemic's initial phase $(\mathrm{F} 1)$, variables retail \& recreation $\left(\mathrm{X}_{41}\right)$, grocery \& pharmacy $\left(\mathrm{X}_{42}\right)$, parks $\left(\mathrm{X}_{43}\right)$, transit stations $\left(\mathrm{X}_{44}\right)$, and workplaces $\left(\mathrm{X}_{45}\right)$ were negatively correlated with the number of COVID-19 cases. Similar to the correlation with mobility, when COVID-19 cases increase per day, the number of activities decreases. While the residential variable $\left(\mathrm{X}_{45}\right)$ has a positive value, people are increasingly staying at home when the number of COVID-19 cases rises.

In the phase of F2, F3, and F4, variables $\mathrm{X}_{41}, \mathrm{X}_{42}, \mathrm{X}_{43}$, dan $\mathrm{X}_{45}$ correlate with the number of COVID19 cases that are relatively low and positive value. This low value shows that the number of people active in the city does not affect the number of COVID-19 cases. In the PSBB and AKB phases, the implementation of COVID-19 health protocols has been implemented and adhered to in Surabaya.

In the AKB phase (F4), the correlation value between transit stations $\left(\mathrm{X}_{44}\right)$ and the number of highvalue and positive-value cases was 0.688 . While the correlation between residential $\left(\mathrm{X}_{46}\right)$ and the number of cases is high but negative, which is -0.573 . This value shows that during AKB, the number of COVID-19 cases in Surabaya is influenced by the number of people who are active / gathered at transit stations, as well as the lack of people who are active in residential

\section{Conclusions}

Mobility and activities patterns of Surabaya people in 2020 are influenced by the spread of COVID19 and government policies to reduce its spread. Mobility and activity patterns can be divided into 5 phases of conditions, namely normal condition phase (F0), pandemic's initial phase (F1), large-scale social restriction phase (F2), the transition of new habit adaptation phase (F3), and new habit adaptation phase (F4).

The number of positive cases of COVID-19 has a high correlation to the mobility of people and vehicles in Surabaya. The type of mobility that most affects the increase in COVID-19 cases is mobility in bus transport modes with varying correlation values in each phase. Meanwhile, the correlation between the number of positive cases of COVID-19 and the activities of people obtained from Community Mobility Reports has a relatively low correlation. However, in the F4, the number of activities in transit stations and residential areas is highly correlated to COVID-19 cases.

\section{References}

[1] R. Djalante et al., "Review and analysis of current responses to COVID-19 in Indonesia: Period of January to March 2020," Prog. Disaster Sci., vol. 6, p. 100091, 2020, DOI: 
10.1016/j.pdisas.2020.100091.

[2] Gugus Tugas Percepatan Penanganan COVID-19, "Laporan Kasus Harian Satgas Penanganan COVID-19," 2021. [Online]. Available: https://covid19.go.id/peta-sebaran.

[3] S. M. Iacus, C. Santamaria, F. Sermi, S. Spyratos, D. Tarchi, and M. Vespe, "Human mobility and COVID-19 initial dynamics," Nonlinear Dyn., vol. 101, no. 3, pp. 1901-1919, 2020, DOI: 10.1007/s11071-020-05854-6.

[4] M. U. G. Kraemer et al., "The effect of human mobility and control measures on the COVID-19 epidemic in China," Science (80-. )., vol. 368, no. 6490, pp. 493-497, 2020, DOI: 10.1126/science.abb4218.

[5] A. Tirachini and O. Cats, "COVID-19 and public transportation: Current assessment, prospects, and research needs," J. Public Transp., vol. 22, no. 1, pp. 1-34, 2020, DOI: 10.5038/23750901.22.1.1.

[6] Google, "Google COVID-19 Community Mobility Reports," 2021. https://www.google.com/covid19/mobility/.

[7] S. Santoso, Menguasai Statistik dengan SPSS 25. Jakarta: PT. Elex Media Komputindo, 2018.

[8] Dinas Perhubungan Kota Surabaya, "Data Arus Bus dan Penumpang AKAP AKDP Unit Terminal Purabaya Tahun 2020," 2020.

[9] PT. Kereta Api Indonesia DAOP VIII Surabaya, "Volume Penumpang Surabaya Gubeng Tahun 2020," 2020.

[10] PT. Jasa Marga Cabang Surabaya Gempol, "Data Lalu Lintas Tol Surabaya Gempol Tahun 2020," 2020. 